Ann. Biol. anim. Bioch. Biophys., 1978, 18 (3), 721-734

\title{
Induced lactation in cows and heifers by short-term treatment with steroid hormones
}

\author{
par C. DELOUIS, J. DJIANE, G. KANN, M. TERQUI *, H. H. HEAD ** \\ avec la collaboration de J. PONT, Y. de FONTAUBERT, P. CHESNÉ \\ Laboratoire de Physiologie de la Lactation, I. N. R. A. \\ 78350 jouy en josas, France \\ * Station de Physiologie de la Reproduction, I. N. R. A. \\ Nouzilly 37380 Monnaie, France \\ ** Dairy Science Department, University of Florida, Gainesville. \\ Florida, 32611, U. S. A.
}

\begin{abstract}
Summary. Induction of lactation following administration of estradiol-17 $\beta$ and progesterone for 7 consecutive days was investigated in heifers and non-lactating multiparous cows of the Friesian breed. Lactation started 14 days after the end of the treatment with steroids.

Mean milk yields for 32 induced lactations were between 2000 and $3000 \mathrm{~kg} / 300$ days except for two heifers which failed to respond to the treatment $(50 \mathrm{~kg} / 120$ days and $650 \mathrm{~kg} /$ 150 days, respectively). Mean milk yield for the multiparous cows was $80 \mathrm{p} .100$ of that produced during previous natural lactations whereas heifers produced only 60 p. 100 of milk yield recorded during natural lactations which followed the induced lactation. Milk yields during 21 induced lactations in cows and heifers and during natural lactations in the same animals were correlated $(r=+0.47, P<0.05)$.

Plasma concentrations of total estrogens, progesterone and prolactin revealed that mammary gland growth and lactogenesis occurred when steroid concentrations had decreased and prolactin had increased. Additional treatment with hydrocortisone acetate for 3 days, coincident with the time milking began, had a positive effect on subsequent milk yields $(P<0.001)$.

Increasing the amounts of estradiol-17 $\beta$ and progesterone injected did not resulf in greater milk yields but did result in an increase in the post-treatment frequency of cystic follicles.

Ten cows and 13 heifers were inseminated during the induced lactation. One cow and one heifer failed to conceive, two heifers conceived but subsequently aborted, and the other cows and heifers conceiving showed normal pregnancy, parturition and lactation.

These results demonstrate that cows and heifers can be induced into lactation successfully using steroid injections of short duration. This procedure may be of practical value to induce lactation in high producing cows of low fertility. Additionally, it may be useful for early selection of dairy cows.
\end{abstract}

\section{Introduction.}

Induction of lactation in dairy cows has been obtained following administration of estrogens and progesterone for 60 to 180 days (Turner et al., 1956 ; Meites, 1961). Results of these induced lactations were variable and the long term treatments requir- 
ed made the procedures of limited practical value. More recently, Smith and Schanbacher (1973) have shown that injection of estradiol-17 $\beta$ and progesterone for 7 consecutive days induced mammary gland growth and lactation in the bovine. Milk yields recorded using this procedure approached those measured during natural lactations following pregnancy. Many subsequent studies have demonstrated the efficacy of this short-term injection protocol.

In order to more fully develop and understand the procedure it is important to evaluate physiological changes produced by the exogenous steroids. This can be accomplished conveniently using a greater number of experimental animals and increasing specific observations. It is important to know, for example, the pattern of plasma hormone concentrations following exogenous steroid injection. Observations of Erb et al. (1976a), based upon a statistical evaluation of plasma hormone concentrations indicated that during hormone-induced lactation there were associations of hormone which seemed more favorable for attaining superior lactations. Furthermore Chakriyarat ef al. (1977) found that rapid post-injection increases in concentration of plasma prolactin were associated with high milk yields during the induced lactation.

One factor limiting establishment of complete lactation might be the absence of sufficient quantities of a single hormone or of the temporal association of several hormones. Glucocorticoids are known to be one part of the lactogenic complex in the cow in vitro (Djiane et al., 1975 ; Collier et al., 1977) and their administration to cattle and sheep during late gestation will induce lactation without concurrent parturition (Tucker and Meites, 1965 ; Delovis and Denamur, 1967). In addition, priming of the mammary gland by estrogen and progesterone during induced lactation may be inadequate compared to that occurring during the second half of gestation.

The subsequent fertility of animals induced to lactate is not sufficiently well documented to allow the development of such a technique in practice.

Experiments were designed in order to evaluate total estrogens, progesterone and prolactin plasma levels, milk yields and subsequent fertility after induction of lactation of nonpregnant multiparous cows and multiparous heifers. Different amounts of ovarian steroids and additive treatments with a corticoid were tested.

\section{Materials and methods.}

Animals. - Multiparous cows ( 2 to 6 previous lactations) and nulliparous heifers of the Friesian breed were used. All animals were housed in individual box stalls during the steroid injections and until the estrus-like sexual activity had subsided. Thereafter they were integrated into the milking herd and fed hay, corn and concentrate according to milk productions. All cows and heifers were milked twice daily (800 and $17.00 \mathrm{hr}$ ) except on Sunday when they were milked only one time (10.00 hr); milking weights were recorded two consecutive days/wk throughout lactation (300 days).

Hormonal treatments. - Estradiol-17 $\beta$ and progesterone (Roussel, France) were dissolved in 95 p. 100 ethanol to give a stock solution containing 20 and $50 \mathrm{mg} / \mathrm{ml}$, 
respectively. Animals were injected twice daily ( 800 and $17.00 \mathrm{hr}$ ) with steroid solution behind the scapula for 7 consecutive days according to Smith and Schanbacher (1973). Injection rates were 0.1 and $0.25 \mathrm{mg} / \mathrm{kg}$ body wgt. / day for estradiol- $17 \beta$ and for progesterone, respectively. On experimental days 19 to $21,25 \mathrm{mg}$ hydrocortisone acetate (Roussel, France) were injected i. m. twice daily ( 800 and $17.00 \mathrm{hr}$ ) and machine milking was initiated on day 21.

Blood sampling. - Blood samples from the jugular vein were obtained by veinipuncture from 8 multiparous cows four times daily $(700,11.00,15.00$ and $19.00 \mathrm{hr}$ ) from 2 days pretreatment to experimental day 8 and then fwice daily (700 and $17.00 \mathrm{hr}$ ) from day 9 to 22 . Plasmas were frozen $\left(-20^{\circ} \mathrm{C}\right)$ until assayed.

Plasma hormones. - Total plasma estrogens and progesterone were estimated by radioimmunoassay according to Terqui et al. (1973) and prolactin as described by Kann (1971).

\section{Results.}

Estrogens. - Concentrations of total plasma estrogens increased sharply during the period of steroid injection (fig. 1). Maximal concentrations (4 to $5 \mathrm{ng} / \mathrm{ml}$ ) were maintained for 1 or 2 days after the injections had ceased, but had returned to essentially pre-treatment levels by days 14 to 15 ( 8 days post-treatment). Maximal concentrations were comparable to those in plasma of pregnant cows at about day 220 of pregnancy (Bedford et al., 1972 ; Smith et al., 1973 ; Terqui et al., 1975).

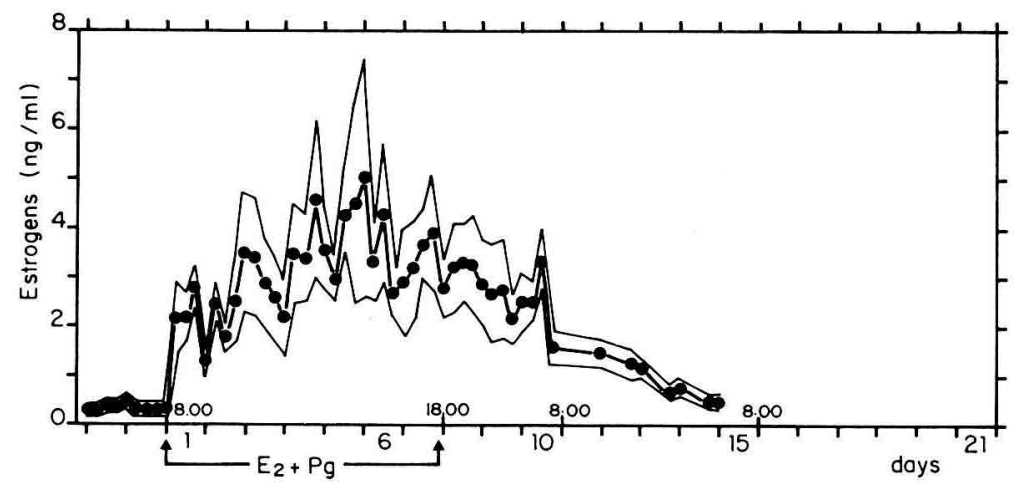

FIG. 1. - Evolution of plasma levels of total estrogens during induced lactation. Results are expressed as estrone equivalent. Mean values of 8 cows (see Materials and methods). Mean \pm SEM.

Progesterone. - Pre-injection basal concentrations were between 1 and $2 \mathrm{ng} / \mathrm{ml}$. Maximal concentrations were obtained early during the steroid injection (days 1 or 2) and plateaued at about $2 \mathrm{ng} / \mathrm{ml}$ throughout the injection phase (fig. 2). Mean plasma concentrations were between 0.5 and $1 \mathrm{ng} / \mathrm{ml}$, one wk after discontinuing the injections. Maximal plasma concentrations reached were essentially comparable to those record- 
ed during the last few days of pregnancy in the cow (Bedford ef al., 1972 ; Smith ef al., Stabenfeldt, 1974).

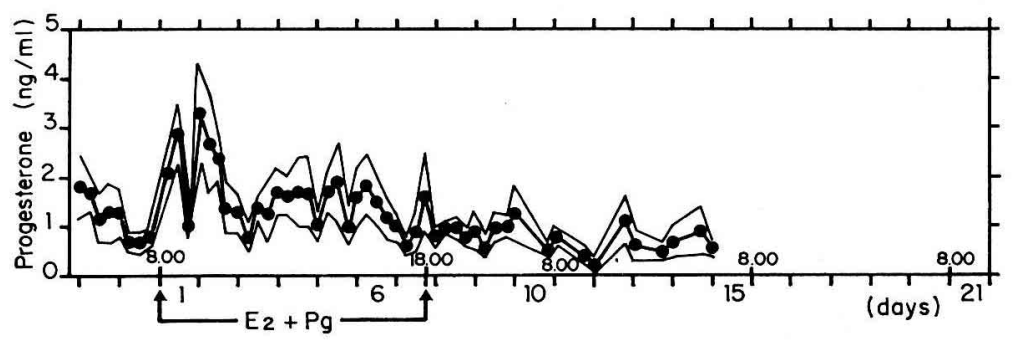

FIG. 2. - Evolution of plasma levels of progesterone during induced lactation. Mean values of 8 cows (see Materials and methods). Mean \pm SEM.

Prolactin. - Steroid injections had no effect upon plasma concentrations of prolactin during the injection phase. Concentrations remained in the range from $20-40 \mathrm{ng} / \mathrm{ml}$ and on experimental day 10 mean concentration was $28 \pm 13 \mathrm{ng} / \mathrm{ml}$. Thereafter plasma concentrations were higher (range 50 to $80 \mathrm{ng} / \mathrm{ml}$ ) with a mean of $60 \mathrm{ng} / \mathrm{ml}$ on day 21 when milking was initiated (fig. 3). A comparable pattern was reported

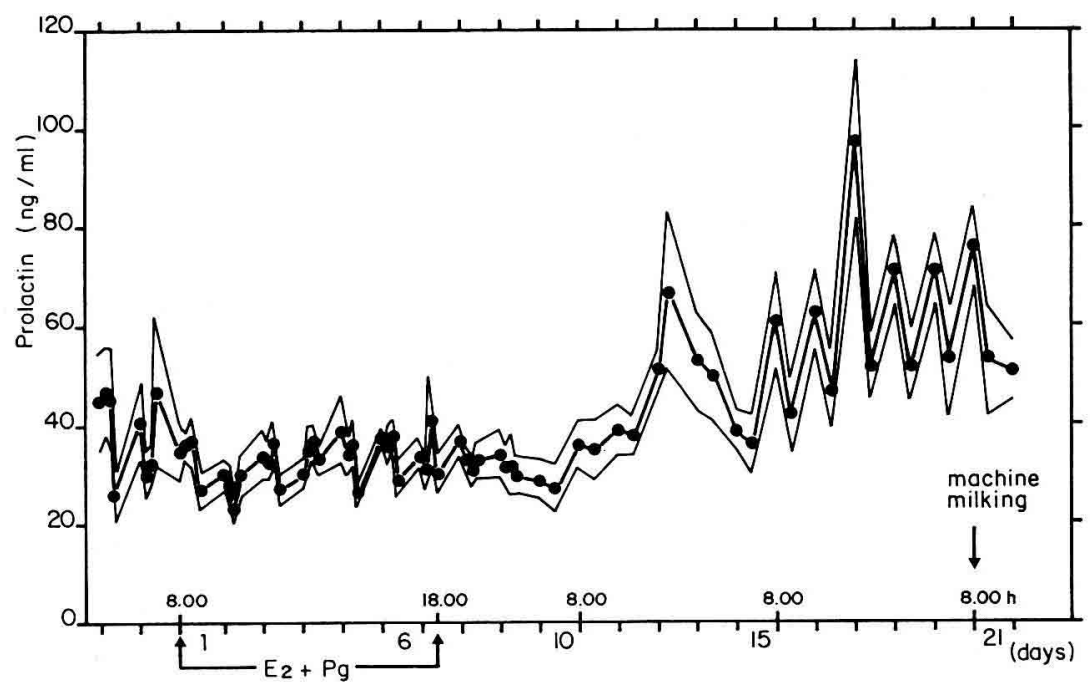

FIG. 3. - Evolution of plasma levels of prolactin during induced lactation. Ovine prolactin NIH PS7 was used as standard. Mean values of 8 cows (see Materials and methods). Mean $\pm S E M$.

PLATE !. - Evolution of mammary gland size during induced lactation (cow 566)
$\mathrm{A}=$ one day before $\mathrm{E}_{2}+\mathrm{Pg}$ treatment ;
$\mathrm{B}=$ day 7 , last day of $\mathrm{E}_{2}+\mathrm{Pg}$ treatment ;
$C=$ day 14 ;
$\mathrm{D}=$ day 21 , before first machine milking which produces 3 I of milk. 
PI. !.
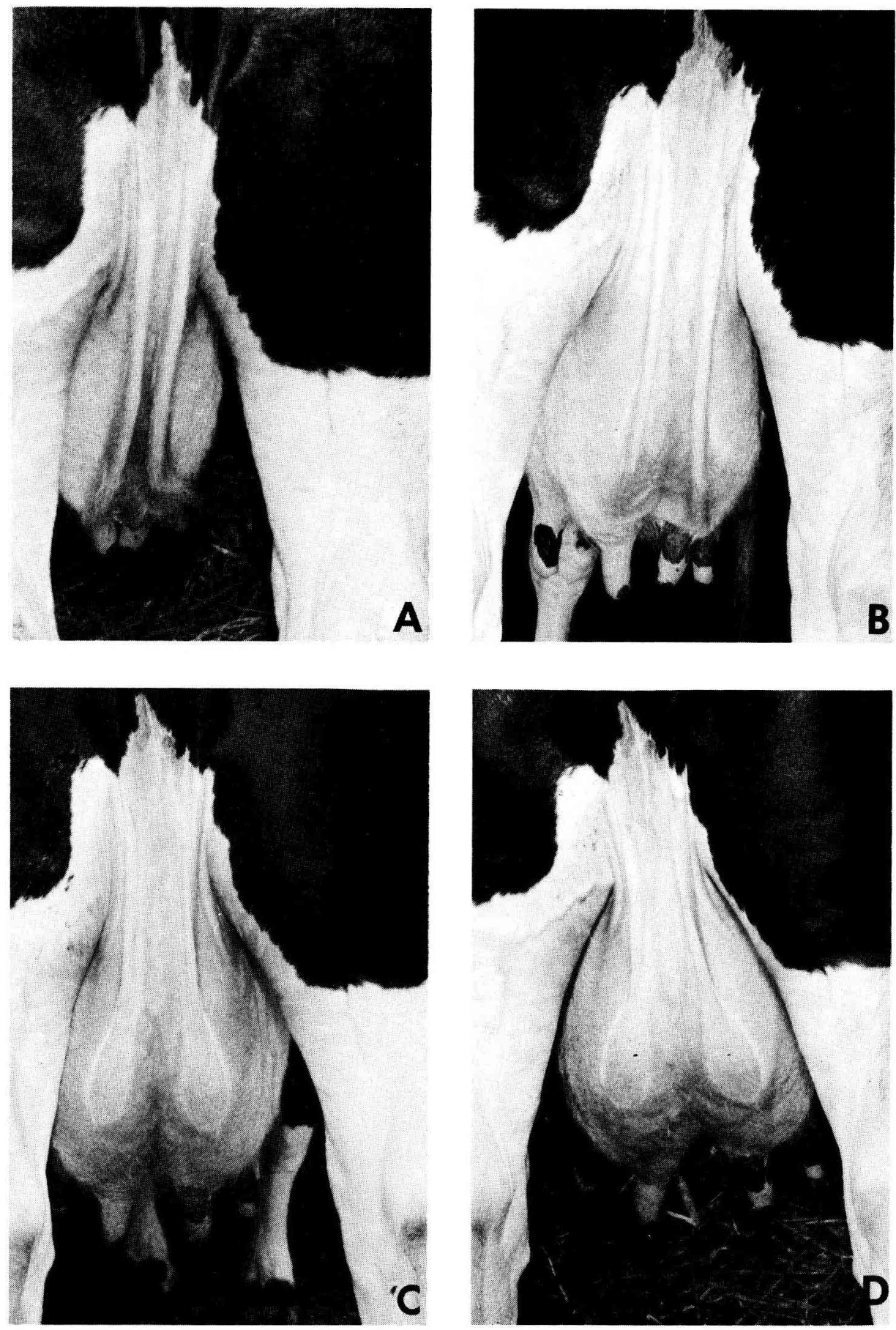
previously by Erb et al. (1976b) ; Schams (1976); Willett et al. (1976) and Chakriyarat et al. (1977). Administration of hydrocortisone did not affect concentrations of prolactin. Maximal plasma concentrations of prolactin following steroid injections were close to those reported during estrus but were significantly less than observed at the time of parturition (Karg and Schams, 1970 ; Johke ef al., 1971).

Mammary gland growth. - Mammary gland growth, as depicted by increased size of the udder, is shown in plate I. There was very limited or no increase during the steroid injection phase ( $a$ and $b$ ) but udder size increased significantly between days 7 and 21 (b, c, and d). This increase continued after milking was initiated.

Corticoid treatment effects. - Eight multiparous non-lactating cows, 8-10 years old, received estradiol-17 $\beta$ and progesterone for 7 consecutive days, as described previously. Additionnally, four of the cows received intramuscular injections of corticoid ( $25 \mathrm{mg}, 2 \times$ /day, hydrocortisone acetate) on days 19 to 21 . Milking was initiated on day 21 and milk yields recorded throughout a 70-day period.

Milk yields for the 4 cows injected with corticoids were higher $(P<0.01$, table 1$)$. Magnitude of milk synthesis and peak yield/ddy both were higher. However, time to achieve peak yield did not differ between the two groups. Milk yields recorded after the treatment including hydrocortisone acetate were low $(460 \mathrm{~kg} / 70 \mathrm{~d}$, table 1). This result was probably due to the absence of a complete involution of the mammary gland at the time of treatment with ovarian steroids, the cows included in this assay having been non-lactating for a 3-wk period. The effects of corticoid treatment on milk yield could have been direct or indirect. However, they were not mediated by altered concentrations or apparent availability of other hormones since corticoid treatment did not affect plasma concentrations of other hormones (fig. 1-3).

\section{TABLE 1}

Effect of hydrocortisone on milk yields of multiparous, non-lactating cows induced into lactation

\begin{tabular}{|c|c|c|c|c|c|}
\hline \multirow[b]{2}{*}{ Treatments } & \multirow[b]{2}{*}{ Cow No } & \multicolumn{4}{|c|}{ Milk yields } \\
\hline & & $\begin{array}{c}\text { Mean/day } \\
\mathrm{kg}\end{array}$ & $\begin{array}{l}\text { Peak } \\
\mathrm{kg}\end{array}$ & $\begin{array}{r}\text { Total } / 70 \text { days } \\
\text { kg }\end{array}$ & Day of peak \\
\hline$E_{2}+P g$ & $\begin{array}{r}96 \\
302 \\
508 \\
996\end{array}$ & $\begin{array}{l}3.7 \\
3.6 \\
0.6 \\
1.4\end{array}$ & $\begin{array}{l}7.2 \\
5.1 \\
1.6 \\
2.2\end{array}$ & $\begin{array}{r}261 \\
280 \\
42 \\
100\end{array}$ & $\begin{array}{l}35 \\
70^{a} \\
49 \\
35\end{array}$ \\
\hline $\mathrm{E}_{2}+\mathrm{Pg}+\mathrm{H}$ & $\begin{array}{c}\text { Mean } \pm \text { SEM } \\
52 \\
128 \\
566 \\
948\end{array}$ & $\begin{array}{c}2.3 \pm 0.8 \\
5.9 \\
3.4 \\
9.6 \\
7.4\end{array}$ & $\begin{array}{c}3.9 \pm 1.4 \\
8.5 \\
4.8 \\
11.5 \\
8.5\end{array}$ & $\begin{array}{c}163 \pm 55 \\
413 \\
238 \\
671 \\
517\end{array}$ & $\begin{array}{l}47 \pm 8 \\
49 \\
70^{a} \\
42 \\
49\end{array}$ \\
\hline & Mean \pm SEM & $6.6 \pm 1.3$ & $8.3 \pm 1.4$ & $460 \pm 91$ & $52 \pm 6$ \\
\hline
\end{tabular}

$a$ : daily milk yields were still increasing. 
TABLE 2

Effect of two doses of estradiol-17 $\beta$ and progesterone on the milk yields during induced lactation in multiparous non-lactating cows and heifers

\begin{tabular}{|c|c|c|c|c|}
\hline \multirow[b]{2}{*}{ Treatments } & \multicolumn{3}{|c|}{ Milk yields } & \multirow{2}{*}{$\begin{array}{c}\text { Mean daily gain } \\
\text { to the peak of lactation } \\
\mathrm{kg} / \text { day }\end{array}$} \\
\hline & $\begin{array}{r}\text { Total } / 300 \text { days } \\
\text { kg }\end{array}$ & $\begin{array}{l}\text { Peak } \\
\mathrm{kg}\end{array}$ & Day of peak & \\
\hline \multicolumn{5}{|l|}{$\begin{array}{l}\mathrm{E}_{2}(0.1 \mathrm{mg} / \mathrm{kg} \mathrm{b} . \mathrm{w} . / \mathrm{d}) \\
\mathrm{Pg}(0.25 \mathrm{mg} / \mathrm{kg} \text { b.w. } / \mathrm{d}) \\
\mathrm{H}(25 \mathrm{mg} \text { twice daily })\end{array}$} \\
\hline $\begin{array}{c}\text { Heifers }{ }^{c}(5){ }^{a} \ldots \ldots \\
\text { Cows (7) } \ldots \ldots \ldots \\
\mathrm{E}_{2}(0.2 \mathrm{mg} / \mathrm{kg} \text { b.w. } / \mathrm{d}) \\
\mathrm{Pg}(0.5 \mathrm{mg} / \mathrm{kg} \text { b.w. } / \mathrm{d}) \\
\mathrm{H}(25 \mathrm{mg} \text { twice daily })\end{array}$ & $\begin{array}{l}2461 \pm 149^{b} \\
2779 \pm 285\end{array}$ & $\begin{array}{l}9.2 \pm 1.0 \\
9.0 \pm 0.8\end{array}$ & $\begin{array}{l}95 \pm 12 \\
90 \pm 10\end{array}$ & $\begin{array}{l}0.10 \pm 0.01 \\
0.11 \pm 0.02\end{array}$ \\
\hline $\begin{array}{lll}\text { Heifers }^{d}(8) & \ldots \ldots \\
\text { Cows } & (3) & \ldots\end{array}$ & $\begin{array}{l}2220 \pm 80 \\
2499 \pm 277\end{array}$ & $\begin{array}{r}9.3 \pm 1.3 \\
11.5 \pm 0.9\end{array}$ & $\begin{array}{l}90 \pm 4 \\
70 \pm 10\end{array}$ & $\begin{array}{l}0.11 \pm 0.01 \\
0.17 \pm 0.03\end{array}$ \\
\hline
\end{tabular}

$E_{2}$ and $\mathrm{Pg}$ were administrered for 7 days (days 1 to 7 ) and $\mathrm{H}$ for 3 days (days 19 to 21).

$a$ : number of animals; $b$ : mean \pm SEM; $c$ : one heifer which produced $650 \mathrm{~kg} / 150$ days was not considered; ${ }^{a}$ : one heifer which produced $50 \mathrm{~kg} / 120$ days was not considered.

TABLE 3

Milk yields during induced and control lactation in heifers and multiparous non-lactating cows

No animal

Milk yields $(\mathrm{kg} / 300$ days)

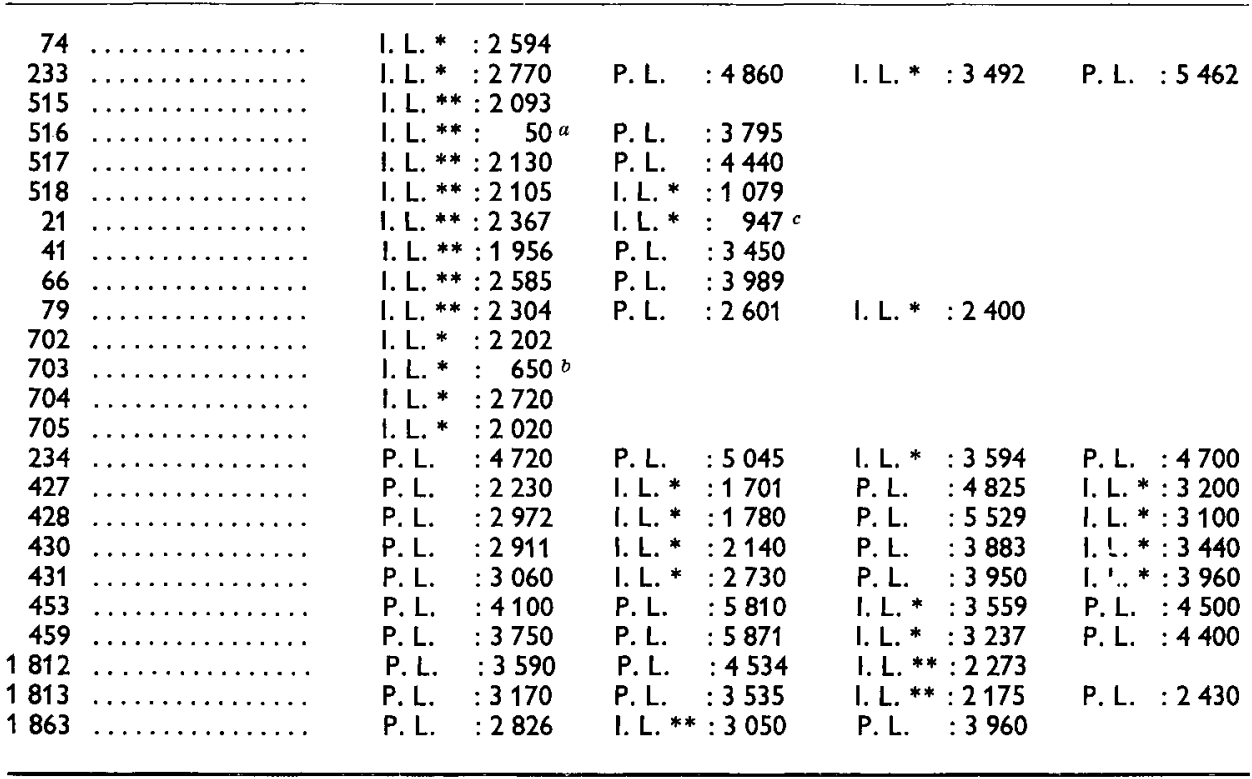

I. L. : Induced lactation ; P. L. : natural lactation.

* : $\mathrm{E}_{2}+\mathrm{Pg}(0.1 \mathrm{mg}, 0.25 \mathrm{mg} / \mathrm{kg}$ body weight/day, during 7 days, respectively).

** : $\mathrm{E}_{2}+\mathrm{Pg}(0.2 \mathrm{mg}, 0.50 \mathrm{mg} / \mathrm{kg}$ body weight/day, during 7 days, respectively).

$a$ : Milk yield/120 days ; ${ }^{b}$ : milk yield/150 days ; ${ }^{c}:$ milk yield/107 days. 
Efficacy of different dosages of estradiol-17 $\beta$ and progesterone. - Milk yields of cows and heifers receiving the normal dose or twice this dose are summarized in tables 2 and 3. Doubling the daily amount of steroid injected had no apparent effect. By all criteria considered, heifers and cows generally responded identically to both doses of steroids. Total, mean daily, peak, day of peak and milk yields were the same. Thus, there was no evidence for differences in lactation curves following steroid hormoneinduced lactation.

Milk yields during hormone-induced or natural lactations. - Comparisons were made of milk yields obtained during the hormone-induced lactation and during a previous or a subsequent natural lactation. Results are presented in table 3 and figure 4.

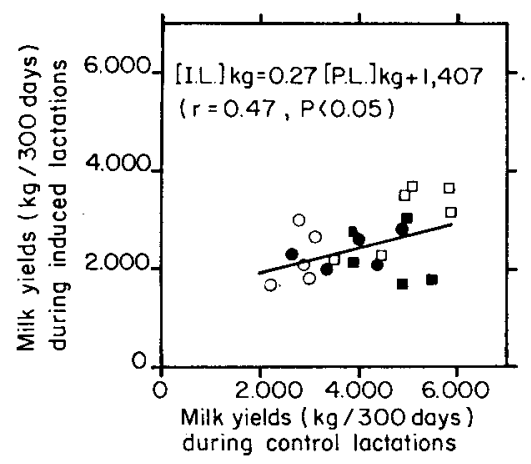

FIG. 4. - Correlation between milk yields recorded during control and induced lactations in the same onimal.

I. L. : Induced lactation ; P. L. : Natural lactation. Nulliparous (•), primiparous (o) and multiparous $(\square,-)$ cows were induced to lactate. The milk yields recorded during induced lactations were plotted using in abcissa the values of milk yields recorded in the same animal during the previous $(o, m)$ or the following natural lactation $(\bullet, \square)$.

Five heifers induced into lactation subsequently became pregnant and had a normal lactation. Milk yields recorded during induced lactation were 61 p. 100 of those recorded during the natural lactation ( 300 days). Five primiparous cows were induced into lactation following calving and natural lactation. Milk yields during the induced lactation were 81 p. 100 of those obtained during the natural lactation. In six multiparous non-lactating cows induced lactations which followed a natural lactation were only 62 p. 100 of previous lactations. In an additional six multiparous non-lactating cows milk yields during induced lactations were 50 p. 100 of those obtained during subsequent natural lactations. Mean milk yield for 21 paired observations showed that treated heifers and cows produced only 65 p. 100 of the milk yield recorded during a normal lactation. There was, however, a significant positive association between milk yields of the induced and natural lactation (fig. $4, r=0.47, P<0.05$ ). This suggests that subsequent lactational performance could be predicted from an induced lactation.

Milk samples collected at random during the induced lactation showed that milk fat and nitrogen content in milk from induced cows was the same as found during natural lactations, in agreement with previous reports of Narendran et al. (1974) and Schanbacher and Smith (1975). 


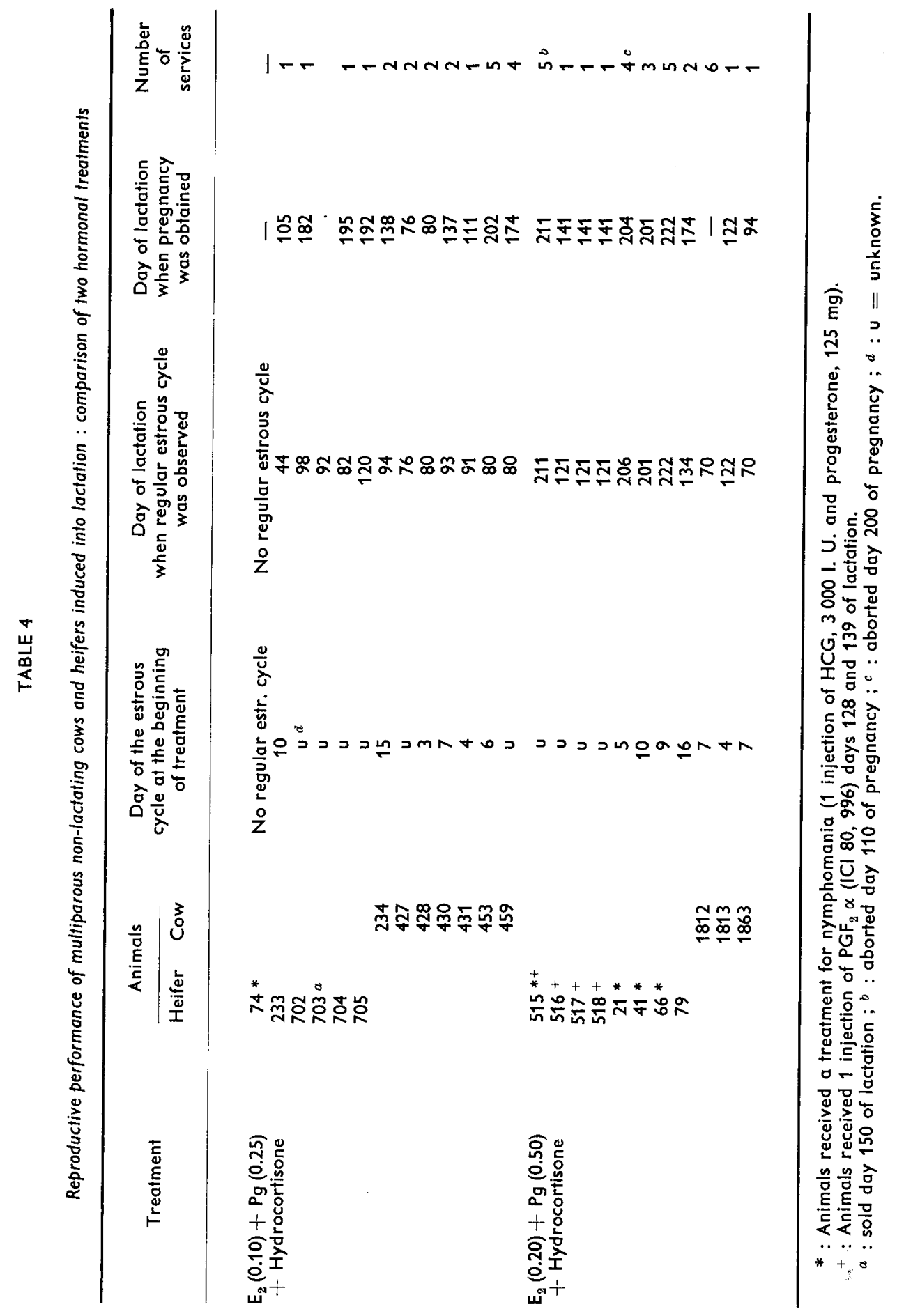


Reproductive performance. - Reproductive performance of 12 heifers and 10 cows was monitored following the induction of lactation (table 4). All cows except one and all heifers, except two, became pregnant. Lactation occurred after normal calving.

However, reproductive performance was reduced for four heifers which had received the higher dose of estradiol-17 $\beta$ and progesterone and failed to show regular estrous cycle activity during the induced lactation. Cystic follicles were detected on their ovaries. Treatment with HCG ( $3000 \mathrm{IU}$ and progesterone, $125 \mathrm{mg}$ ) was effective in restoring normal estrous cycles and they became pregnant. The subsequent fertility was not reduced for the cows which had received the higher dose of estradiol-17 $\beta$ and progesterone; they showed regular estrous cycles within 2 months of lactation. One cow (1812) failed to conceive to 6 repeat breedings. Ovaries of four other cows were examined each month during the induced lactation by endoscopy, and plasma concentrations of progesterone were controlled in the animals. Two of the four cows received the higher dose of ovarian steroids and appearance of the first estrous cycle was delayed by more than an additional month. However, cystic follicles did not develop in any of the animals receiving twice the dose rate.

Estrus cycle activity was recorded prior to steroid injections for some of the cows and heifers (table 4). Steroid injections were initiated between days 3 and 10 of the estrous cycle, except for one cow injected at the end of the cycle and one heifer which showed no regular cyclic activity.

From these observations, it seems that the subsequent fertility of induced cows was not probably related to the time of estrous cycle where the treatment with ovarian steroids was initiated.

\section{Discussion.}

Concentrations of total estrogens and progesterone in plasma (fig. 1 and 2) following estrogen-progesterone injections were of the same order of magnitude as obtained during late gestation (Terqui et al., 1975 ; Stabenfeldt, 1974) but much higher than observed at the time of estrus (Saumande and Lopez-Sebastian, 1977). Although the pattern was similar to that reported previously (Monk et al., 1973 ; Erb ef al., $1976 a, b)$ plasma concentrations of estrogens were higher since both conjugated and unconjugated estrone and estradiol ( $\alpha$ and $\beta$ ) were measured.

At the time machine milking was initiated (day 21) concentrations of plasma estrogens and progesterone were low and the milk obtained did not contain significant quantities of these steroids (unpublished observations). The rapid decrease in plasma concentrations of these steroids following cessation of injections doubtlessly resulted from rapid metabolism and fecal and urinary excretion (Monk et al., 1973 ; Erb et al., 1976a and Willett et al., 1976).

Growth and enlargement of the mammary glands (udder) occurred after experimental day 14 (plate I) by which time concentrations of plasma steroids already were declining (fig. 1 and 2). This increase of the udder size coincided with the increase in plasma concentrations of prolactin (fig. 3) as previously observed (Schams, 1976 ; Chakriyarat et al., 1977). It also corresponded to the period where Smith and Schanbacher (1973) and Chakriyarat ef al. (1977) observed a rapid accumulation of secre- 
tions and Collier et al., (1975) and Croom ef al., (1976) the cellular differenciation of the developing mammary gland.

Including injections of hydrocortisone in the induction schema was highly beneficial (table 1). This agrees with the results of Fulkerson and McDowell (1975) and Chakriyarat ef al. (1977) and suggests that availability of corticoids might be ratelimiting in cows induced into lactation or alternately, that temporal associations among corticoids, other steroids and protein hormones during the induction were less than optimal. Administration of corticoids at relatively high doses to sheep (Delouis and Denamur, 1967) and cows (Tucker and Meites, 1965) during gestation will induce lactogenesis without concomitant parturition. These results and those observed during hormone-induced lactation suggest an insufficiency of corticoids. The increase in success rate (Chakriyarat et al., 1977) and induced lactation milk yields when a corticoid source was included (table 1 ; Fulkerson and McDowell, 1975) was demonstrated, whereas increasing the dosage rate of steroids injected in the 7-day protocol was not beneficial. Increasing the length of estrogen-progesterone injections from 7 to 10 days (Smith and Schanbacher, 1973) or up to 21 days (Chakriyarat et al., 1975) has given varied results. Altering the time sequence when corticoids are administrered might be one more effective way to provoke greater mammogenesis and lactogenesis (Convey, 1974 ; Djiane ef al., 1975).

Milk yields recorded during hormone-induced lactations were 60 to 80 p. 100 of those obtained during natural lactations in the same animals (table 3, fig. 4). Comparable results have been obtained by a number of workers (Paape et al., 1973 ; Collier et al., 1975 ; Chakriyarat ef al., 1977). However, success rates following steroid injections were more consistent than reported by Smith and Schanbacher (1973) and Collier et al. (1975). During the current studies only two heifers failed to lactate. Although not tested statistically lowest milk yields apparently were obtained from experimental animals which had been dry for only a short period before steroid injections were initiated (table 1).

Peak milk yields during the hormone-induced lactation generally were obtained after 90 days in cows and even later in heifers. This agrees with the delay to peak observed by Collier ef al. (1975). Peak yields were obtained early in the lactation only in animals which had low milk yields. Reasons for variations in time to attain peak yield are unknown but may be due to such factors as : breed of cow, steroid injection protocol used, prior physiological status of the induced animal, hormones released in response to milking stimuli and extent of mam mogenesis or lactogenesis during induced lactation. The positive correlation $(r=0.47)$ between induced and natural lactation milk yields (fig. 4) is, as far as we know, the first to illustrate that induced lactations may have predictive value. However, it will be necessary to extend observation sets and comparisons in order to more firmly establish this relationship and examine potential differences among cows. It has the potential, however, of providing another means of estimating producing ability of heifers at an early age. Also it may provide a means to establish the limits of milk production expected for infertile cows which are to be induced.

Return of cows and heifers to apparently normal estrous cycle activity occurred between experimental days 80 and 100 . No differences were noted in return to cyclic activity of cows and heifers receiving the normal dose $(0.10$ estradiol-17 $\beta$ and $0.25 \mathrm{mg}$ 
progesterone/kg body wt/day). However, development of cystic follicles occurred more frequently in heifers than in cows which had been injected with a daily dose of steroid twice the normal. Also conceptions following A. I. were delayed in animals receiving the higher steroid injection rate. Thus, there was no overall benefit from increasing estrogen-progesterone exposure during the induction. Comparable reproductive success has been achieved using normal steroid injection rates (Smith and Schanbacher, 1973 ; Collier ef al., 1975). There are no known experiments which compare efficacy of even lower estrogen-progesterone injection rates and subsequent reproductive performance to evaluate whether further improvements over those observed (table 4) would result without diminishing lactational performance.

Reçu en octobre 1977. Accepté en février 1978.

Résumé. L'induction de la lactation après administration d'œstradiol $17 \beta$ et de progestérone pendant 7 jours consécutifs a été réalisée chez des génisses et des vaches multipares taries, de race Frisonne. La lactation commence 14 jours après l'arrêt du traitement.

La moyenne des productions laitières de 32 inductions se situe entre 2000 et $3000 \mathrm{~kg} /$ 300 jours à l'exception de 2 génisses qui n'ont produit que de faibles quantités de lait après le traitement ( $50 \mathrm{~kg} / 120$ jours et $650 \mathrm{~kg} / 150$ jours, respectivement). Les vaches multipares ont une production moyenne de 80 p. 100 de celle mesurée au cours de leur précédente lactation après gestation, alors que les génisses onf une production moyenne limitée à 60 p. 100 de celle mesurée au cours de la lactction de référence qui suit la lactation induite. Les productions laitières enregistrées au cours des lactations induites et au cours des lactations de référence chez les mêmes 21 vaches et génisses sont corrélées $(r=+0,47$, $P<0,05$ ).

La mesure des concentrations plasmatiques des œstrogènes totaux, de la progestérone et de la prolactine révèle que la croissance de la glande mammaire et la montée laiteuse surviennent lorsque les niveaux des stéroides diminuent et ceux de la prolactine augmentent. Un traitement complémentaire avec l'acétałe d'hydrocortisone pendant 3 jours, au moment du passage à la traite, augmente significativement $(P<0,001)$ la production laitière mesurée pendant la lactation induite.

Une administration de quantités 2 fois plus élevées d'œstradiol $17 \beta$ et de progestérone que celles utilisées normalement ne provoque pas une augmentation de la production laitière mais a pour résultat l'apparition plus fréquente de follicules kystiques sur les ovaires. Dix vaches et 13 génisses ont été inséminées pendant la lactation induite. Une vache et une génisse ne sont pas devenues gestantes, 2 génisses ont avorté (le $110^{\mathrm{e}}$ ef le $220^{\mathrm{e}}$ jour de la gestation, respectivement) et les autres animaux ont eu une gestation suivie d'une lactation normale.

Ces résultats mentrent, comme cela a été observé précédemment, que les vaches et les génisses peuvent être soumises avec succès au traitement hormonal d'induction de la lactation utilisant une administration de courte durée de stéroides ovariens. Cette technique serait intéressante pour assurer l'entrée en lactation de vaches subfertiles à haut potentiel laitier. De plus, elle permettrait de prédire la valeur laitière des génisses.

\section{References}

BEDFORD C. A., CHALLIS J. R. G., HARRISON F. A., HEAP R. B., 1972, Role of œistrogens and progesterone in the onset of parturition in various species in control of parturition. J. Reprod. Fert. Suppl., 16, 1-23. 
CHAKRIYARAT S., HEAD H. H., THATCHER W. W., BACHMAN K. C., WILCOX C. J., 1975. LaCtational responses of ovariectomized cows to two hormonal injection schemes. J. Dairy Sci., 58, 140.

CHAKRIYARAT S., HEAD H. H., THATCHER W. W., NEAL F. C., WILCOX C. J., 1977. Induction of lactation : lactational, physiological and hormonal responses in the bovine. J. Dairy Sci. (submitted).

COLLIER R. J., BAUMAN D. E., HAYS R. L., 1975. Milk production and reproductive performance of cows hormonally induced into lactation. J. Dairy Sci., 58, 1524.

COLLIER R. J., BAUMAN D. E., HAYS R. L., 1977. Lactogenesis in explants cultures of mammary tissue from pregnant cows. Endocrinology, 100, 1192-1200.

CONVEY E. M., 1974. Serum hormone concentration in ruminants during mammary growth, lactogenesis and lactation. A review. J. Dairy Sci., 57, 905-917.

CROOM W. J., COLLIER R. J., BAUMAN D. E., HAYS R. L., 1976. Cellular studies of mammary tissue of cows hormonally induced into lactation : histology and ultrastructure. J. Dairy Sci. 59, $1232-1246$.

DELOUIS C., DENAMUR R., 1967. Induction expérimentale de la sécrétion lactée pendant la gestation de la Brebis. C. R. Acad. Sci. Paris, Sér. D, 264, 2493-2496.

DJIANE J., DELOUIS C., DENAMUR R., 1975. Lactogenesis in organ cultures of heifer mammary tissue. J. Endocr., 65, 453.454.

ERB R. E., MALVEN P. V., MONK E. L., MOLLETT T. A., SMITH K. L., SCHANBACHER F. L.. WILLETT L. B., 1976a. Hormone induced iactation in the cow. IV. Relationships between lactational performance and hormone concentrations in blood plasma. J. Dairy Sci., 59, 1420-1428.

ERB R. E., MONK E. L., MOLLETT T. A., MALVEN P. V., CALLAHAN C. J., 1976b. Estrogen, progesterone, prolactin and ofher changes associated with bovine lactation induced with estradiol-17 $\beta$ and progesterone. J. anim. Sci., 42, 644-654.

FULKERSON W. J., MCDOWELL G. H., 1975. Artificial induction of lactation in cattle by use of dexamethasone trimethylacetate. Aust. J. biol. Sci., 28, 121-132.

JOHKE T., FUSE H., OSHIMA M., 1971. Changes in plasma prolactin levels during late pregnancy and early lactation in the goat and the cow. Japan J. zootech. Sci., 42, 173-178.

KANN G., 1971. Dosage radioimmunologique de la prolactine plasmatique chez les ovins. $C$. $R$. Acad. Sci. Paris, Sér. D, 272, 2808-2811.

KARG H., SCHAMS D., 1970. Discussion on prolactin levels in bovine blood under different physiological conditions, 141-143. In FALCONNER I. R., Lactation. Butterworth and Co, London.

MEITES J., 1961. Farm Animals : hormonal induction of laciation and galactopoeisis, 321-367. In KON S., COWIE A. T. Milk. The mammary gland and its secretion. Vol. 11, Acad. Press, New York.

MONK E. L., MOLLETT T. A., ERB R. E., CALLAHAN C. J., 1973. Hormones changes with lactation induced with progesterone-estrogen. J. Dairy Sci, 56, 656.

NARENDRAN R., HACKER R. R., BATRA T. R., BURNSIDE E. B., 1974. Hormonal induction of lactation in the bovine. Mammary gland histology and milk composition. J. Dairy Sci., 57, 1334-1340.

PAAPE M. J., GUIDRY A. J., APRIL M., 1973. Preliminary observation following hormonally induced lactation. J. Dairy Sci., 56, 657.

SAUMANDE J., LOPEZ-SEBASTIAN A., 1977. The validity of conjugated œstrogen measurements as reflection of folliculogenesis in the cow. Joint Meeting SSF-SNESF (Nottingham, March 1977).

SCHAMS D., 1976. Hormonal control of lactation. CIBA Found. Symp., 45, 27-48.

SCHANBACHER F. L., SMITH K. L., 1975. Formation and role of unusual whey proteins and enzymes : relation to mammary function. J. Dairy Sci., 58, 1048-1062.

SMITH K. L., SCHANBACHER F. L., 1973. Hormone induced lactation in the bovine. I. Lactational performance following injections of $17 \mathrm{\beta}$-estradiol and progesterone. J. Dairy Sci., 56, 738-743.

SMITH V. G., EDGERTON L. A., HAFS H. D., CONVEY E. M., 1973. Bovin serum estrogens, progestins and glucocorticoids during late pregnancy, parturition and early lactation. J. anim. Sci., 36, $391-396$.

STABENFELDT G. H., 1974. The role of progesterone in parturition : premature, normal and pro. longed gestation, 97-122. In BOSC M. J., PALMER R., SUREAU Cl., Avortement ef parturition provoqués. Masson et Cie, Paris. 
TERQUI M., DELOUIS C., THIMONIER J., ORTAVANT R., 1975. Relations entre les œstrogènes aU cours de la gestation, le poids à la naissance et la croissance ultérieure des veaux de race charolaise. C. R. Acad. Sci. Paris, Sér. D, 280, 2789-2792.

TERQUI M., DRAY F., COTTA J., 1973. Variations de la concentration d'œstradiol-17 $\beta$ dans le sang périphérique de la Brebis au cours du cycle œstral. C. R. Acad. Sci. Paris, Sér. D, 277, 1795-1798.

TUCKER H. A., MEITES J., 1965 . Induction of lactation in pregnant heifers with 9 fluoropredinsolone acetate. J. Dairy Sci., 48, 403-405.

TURNER C. W., YAMAMOTO H., RUPPERT H. L., 1956. The experimental induction of growth of the cow udder and the initiation of milk secretion. J. Dairy Sci., 39, 1717-1729.

WILLETT L. B., SMITH K. L., SCHANBACHER F. L., ERB R. E., MALVEN P. V., 1976. Hormone induc. ed lactation in the bovine. III. Dynamics of injected and endogenous hormones. J. Dairy Sci., 59, 504-514. 